\title{
HUBUNGAN ANTARA GAYA ATRIBUSI DENGAN TINGKAT PRESTASI AKADEMIK
}

(Studi Korelasional pada Siswa di Beberapa SMA Negeri di Kota Bandung)

\section{Rosleny Marliani}

Fakultas Psikologi UIN Sunan Gunung Djati Bandung

\begin{abstract}
The goal of this research is to find the crucial factors that influence the level of adolescence's academic achievement. The objective of this research is to study the relationship between adolescence's attributional style with their level of academic achievement. This research was carried out by correlational design.

This research involve adolescence as students of three public senior high school in Bandung City, i.e. SMAN 4, SMAN 8, and SMAN 11. The sample of this study are 459 students selected through random from second and third grade. The students at first grade not selected as sample because them not yet owned the data of achievement. The data of achievement was collected by documentation study, and data of attribution by questionnaire. The data expressed in ordinal scale and analyzed statistically by Rank Spearman.

This study has some outcomes related to the relationship between style of attribution with academic achievement. Students which attributing their academic success with high ability and effort or working hard and attributed their academic failure with lack of effort and luck, tend to attain high achievement. While the students that attributing their academic success with easy task and luck, and attributed their academic failure with lack of ability and difficult task, tend to attain low achievement. Based on the findings, to increasing the level of student's academic achievement can be conducted by train the students to developing the adaptive attribution style, that is to attributing their success academic with ability and effort factors, and to attributing their failure academic with lack of effort an luck.
\end{abstract}

Keywords : attribution, academic achievement

\section{Latar Belakang}

Prestasi akademik (prestasi yang dicapai oleh individu dalam hubungannya dengan aktivitas belajar di sekolah) rendah, dan siswa berprestasi rendah merupakan salah satu isu penting dalam bidang pendidikan. Karenanya, prestasi belajar rendah memiliki implikasi penting bagi kajian dalam bidang psikologi perkembangan sebab prestasi belajar rendah seringkali berhubungan dengan adanya proses perkembangan yang tidak sehat (hambatan dalam perkembangan).
Berbagai studi menunjukkan, bahwa siswa yang kurang berhasil di sekolah atau memiliki prestasi belajar rendah seringkali memperlihatkan berbagai gejala perilaku menyimpang yang tidak kondusif untuk mendorong perkembangannya lebih lanjut. Sebab, sebagaimana dinyatakan oleh Conger (1977) dan Lindgren (1980) bahwa remaja yang mengalami hambatan dalam berprestasi cenderung memperlihatkan berbagai bentuk gangguan psikologis atau problem perilaku seperti merasa rendah diri, kurang percaya diri, 
menarik diri, frustrasi, tak berdaya, cemas, depresi. Mereka juga sering melakukan berbagai tindakan tidak adaptif seperti kenakalan (delinquency), bolos sekolah, dan terlibat dalam penyalahgunaan alkohol dan obat-obatan terlarang.

Sejalan dengan pandangan pakar psikologi pendidikan di atas, pengalaman dan pengamatan penulis juga memperlihatkan bahwa, siswa-siswa berprestasi rendah pada umumnya memperlihatkan perilaku tidak adaptif yang tidak hanya merugikan siswa itu sendiri, tetapi juga orang lain. Beberapa ahli psikologi juga telah menyatakan bahwa pengalaman keberhasilan dan/atau kegagalan di sekolah menjadi salah satu faktor penting yang turut mempengaruhi perkembangan kesehatan psikologis.

Melihat kenyataan ini, masalah prestasi belajar rendah membutuhkan perhatian yang lebih serius lebih dari sekadar melakukan inovasi terhadap kurikulum pendidikan, meningkatkan mutu pembelajaran, meningkatkan fasilitas belajar, maupun dengan memberikan intervensi terhadap siswa.

Berdasarkan hal-hal di atas, penulis melakukan sebuah penelitian yang bermaksud mengungkap secara empirik hubungan antara keyakinan siswa tentang faktor-faktor yang mempengaruhi keberhasilan dan / atau kegagalan akademiknya dengan prestasi akademik. Studi penelitian ini, penulis lakukan pada beberapa Sekolah Menengah Atas di Kota Bandung, yakni SMAN 1, SMAN 4, SMAN 8, dan SMAN 11.
Harus diakui, penelitian ini tidak mengungkap seluruh faktor yang memainkan peran dalam mempengaruhi tingkat prestasi akademik di sejumlah sekolah tersebut. Penulis hanya memusatkan perhatian pada faktorfaktor tertentu yang diduga berhubungan dengan tingkat prestasi akademik tinggi dan rendah pada kelompok sampel yang diselidiki, yaitu 1) Hubungan antara gaya atribusi siswa tentang keberhasilan dengan tingkat prestasi akademiknya, 2) Hubungan antara gaya atribusi kegagalan dengan tingkat prestasi akademik.

Untuk keperluan itu, penulis melakukan wawancara terhadap beberapa siswa di empat SMAN di kota Bandung tersebut yang memperlihatkan fenomena dalam pencapaian prestasi akademik yang relatif sama, yakni SMAN 1, SMAN 4, SMAN 8, dan SMAN 11. Jumlah siswa yang diwawancarai adalah 20 orang. Ke-20 orang siswa tersebut diambil secara random. Dalam wawancara ini penulis menemui siswa secara individual dan meminta mereka untuk menyebutkan faktor-faktor tertentu yang mereka yakini sebagai faktor yang mempengaruhi keberhasilan dan / atau kegagalan mereka dalam mencapai / memperoleh prestasi akademik tinggi. Meskipun terdapat variasi, dari wawancara tersebut secara umum ditemukan adanya perbedaan antara kelompok siswa berprestasi tinggi dan kelompok siswa berprestasi rendah dalam menyebutkan faktor-faktor yang mempengaruhi kinerja dan keberhasilan akademiknya. Siswa berprestasi tinggi pada umumnya menyebutkan faktor-faktor internal 
seperti kemampuan yang tinggi dan ketekunan sebagai faktor yang mempengaruhi keberhasilan, dan faktor-faktor eksternal seperti keberuntungan dan tugas yang sulit sebagai penyebab kegagalan.

Sebaliknya, sebagian besar siswa yang memiliki prestasi akademik rendah menyebutkan beberapa kondisi eksternal seperti keberuntungan, kebaikan guru, mata pelajaran yang tidak sulit sebagai faktor yang menyebabkan keberhasilannya, dan kurangnya kecakapan yang menyebabkan kegagalannya. Dari hasil wawancara tersebut tampak bahwa terdapat perbedaan dalam keyakinan yang dipegang oleh siswa berprestasi tinggi dan siswa berprestasi rendah menyangkut faktorfaktor internal dan eksternal yang mempengaruhi keberhasilan dan/atau kegagalan akademiknya. Namun, informasi yang diperoleh dari wawancara tersebut belum dapat digunakan atau diperlakukan sebagai data yang valid untuk tujuan membuat generalisasi. Untuk memperoleh data yang valid perlu dilakukan penelitian lebih lanjut secara sistematis. Penelitian ini dilaksanakan untuk maksud tersebut.

Dari seluruh siswa yang diamati, yakni sebanyak 507 siswa, ditemukan sebanyak 47\% di antaranya memperlihatkan prestasi belajar rendah (dibawah rata-rata). Persentase tersebut dapat dikatakan tinggi karena hampir mendekati lima puluh persen dari seluruh sampel yang diselidiki.

\section{Atribusi sebagai Landasan Teori}

Landasan teori yang dipergunakan penulis mengembangkan penelitian tentang faktor-faktor tertentu yang diduga berhubungan dengan tingkat prestasi akademik tinggi dan rendah tersebut adalah teori atribusi. Teori ini sengaja dipilih karena banyak digunakan sebagai kerangka kerja dalam penelitian-penelitian mutakhir tentang kinerja dan prestasi akademik (Steinberg, 2002).

Teori ini menekankan pada pentingnya keyakinan individu tentang faktor-faktor yang mempengaruhi keberhasilan dan kegagalan akademiknya. Sebagai contoh, beberapa penelitian mutakhir yang dilakukan oleh beberapa peneliti (Harter et al., 1991; Little et al., 1995; MacIver et al., 1991; Marsh, 1990; Pintrich et al., 1994) seperti dilaporkan oleh Steinberg (2002), menyatakan bahwa keyakinan siswa tentang faktor-faktor tertentu yang menyebabkan keberhasilan dan/atau kegagalannya memberikan pengaruh kuat terhadap motivasi dan ketekunan mereka dalam belajar, dan ini selanjutnya mempengaruhi kinerja skolastik mereka. Teori atribusi memberikan penjelasan tentang hubungan antara tingkat prestasi dengan keyakinan individu tentang faktor-faktor tersebut. Menurut para ahli dalam teori atribusi (Dweck, 1980; dan Weiner. 1979, 1986), siswa yang memiliki motivasi berprestasi dan tingkat prestasi akademik tinggi cenderung menyebutkan (mengatribusikan) kemampuan dan ketekunan sebagai faktor yang mempengaruhi keberhasilan mereka, dan menyebutkan kurangnya kerja keras sebagai 
faktor yang menyebabkan kegagalan mereka. Sedangkan para siswa yang kurang memiliki motivasi berprestasi dan yang memiliki prestasi akademik rendah cenderung menyebutkan faktor-faktor eksternal sebagai penyebab keberhasilan mereka, dan kurangnya kemampuan sebagai faktor yang menyebabkan kegagalan.

Beberapa hasil penelitian menyatakan bahwa beberapa bentuk gaya atribusi yang adaptif (facilitative attributional patterns) dapat meningkatkan komitmen dan ketekunan untuk berhasil baik dalam menyelesaikan tugas (bar-Tal, 1978; Marsh et al., 1984; Weiner, 1979, dalam Vispoel \& Austin, 1995). Yang dimaksud dengan gaya atribusi adaptif dalam konteks ini adalah suatu bentuk atribusi tentang keberhasilan dan kegagalan dengan faktor-faktor yang dapat dikendalikan oleh individu.

Teori atribusi pada dasarnya merupakan suatu pendekatan kognitif untuk membuat penjelasan tentang berbagai bentuk atau gejala perlaku (Sullivan \& Howe, 1996), termasuk di dalamnya perilaku berprestasi dan keberhasilan dalam mencapai prestasi di sekolah (prestasi akademik). Teori atribusi yang digunakan dalam penelitian ini adalah teori atribusi dari Bernard Weiner (1986), yang juga sering disebut sebagai attributional theory of achievement (Shaver, 1992; Perlman \& Cozby, 1983). Di kalangan para ahli psikologi, khususnya psikologi pendidikan, Weiner telah diakui sebagai salah seorang tokoh yang pertama kali menerapkan teori atribusi umum ke dalam praktek satu bidang pendidikan (Woolfolk, 1995).

Menurut teori atribusi Weiner (1986), perilaku prestasi (achievement behavior) sangat tergantung pada cara individu menginterpretasikan keberhasilan dan kegagalannya, dan pada apakah ia memiliki keyakinan bahwa ia dapat mengendalikan (mengontrol) keberhasilan dan kegagalan tersebut. Weiner memiliki asumsi bahwa manusia merupakan makhluk pemroses informasi yang aktif, yang berusaha untuk menemukan atau mencari penjelasan tentang faktor-faktor yang menyebabkan keberhasilan atau kegagalan yang dialaminya (hubungan kausalitas), dan pemahaman ini pada akhirnya akan mempengaruhi kognisi, emosi dan perilakunya (Luzo \& Luna, 1996; Perlman \& Cosby, 1983; Shafer, 1992; Weiner, 1986). Berdasarkan pada pemikiran dan hasil-hasil penelitiannya, Weiner (1986) faktor-faktor yang diatribusikan oleh siswa dengan keberhasilan dan/atau kegagalan akademiknya dapat diidentifikasikan dari tiga dimensi sebab, yaitu: (1) lokus kausalitas (locus of causality), (2) stabilitas (stability), dan (3) kontrol (controllability).

Menurut Weiner (1986) ketiga dimensi faktor tersebut memiliki implikasi penting pada motivasi dan tingkat prestasi akademik. Lokus kausalitas memiliki hubungan langsung dengan motivasi berprestasi. Jika keberhasilan atau kegagalan diatribusikan dengan sebab internal, maka keberhasilan akan meningkatkan motivasi, dan pada akhirnya prestasi. Sebaliknya, kegagalan akan merusak 
motivasi dan prestasi. Dimensi stabilitas berhubungan dengan harapan akan keberhasilan dan kegagalan di masa depan. Jika siswa mengatribusikan keberhasilan dan/atau kegagalan dengan faktor yang bersifat relatif permanen atau tak dapat berubah, mereka akan mengembangkan harapan untuk berhasil (atau gagal) pada mata pelajaran atau tes yang sama pada waktu berikutnya. Tetapi jika mereka mengatribusikan keberhasilan dan/atau kegagalan dengan faktor yang tidak stabil (misalnya mood atau keberuntungan), mereka memiliki harapan untuk mencapai hasil yang berbeda (mungkin berhasil, mungkin gagal) pada tugas atau tes yang sama pada waktu berikutnya.

Dimensi kontrol berkaitan dengan emosi, seperti marah, malu, atau perasaan bersyukur. Jika siswa gagal dalam suatu tugas yang ia yakin ia dapat mengontrolnya (dapat berhasil), mereka mungkin akan merasa malu atau bersalah; sedangkan jika berhasil, mereka merasa bangga dan berharga. Individu yang berhasil dalam suatu tugas yang tak dapat dikendalikannya akan merasa beruntung, dan marah jika mengalami kegagalan. Jadi, keyakinan siswa tentang lokus kausalitas akan mempengaruhi penilaian siswa tersebut tentang keberhasilan dan kegagalannya, dan keyakinan siswa tentang stabilitas dari faktor yang menyebabkan keberhasilan dan/atau kegagalannya, dan keyakinan siswa tentang apakah ia dapat mengendalikan faktor-faktor tersebut akan mempengaruhi harapannya di masa depan. Menurut Weiner (1986), dua bentuk pertimbangan tersebut, yakni penilaian dan harapan, memainkan peran penting dalam membentuk kesediaan (motivasi) untuk melakukan aktivitas-aktivitas yang berkaitan dengan prestasi.

Berdasarkan teori atribusi Weiner tersebut dapat disimpulkan bahwa gaya atribusi individu dalam dimensi lokus kausalitas, stabilitas, dan kontrol akan mempengaruhi tingkat motivasi dan hasil-hasil yang berhubungan dengan prestasi. Dengan kata lain, tingkat motivasi dan hasil-hasil perilaku (kinerja) yang berkaitan dengan prestasi akan berkorelasi dengan gaya atribusi individu dalam dimensi kausalitas, stabilitas, dan kontrol. Secara skematis, kerangka pemikiran ini disajikan dalam bagan di bawah ini:

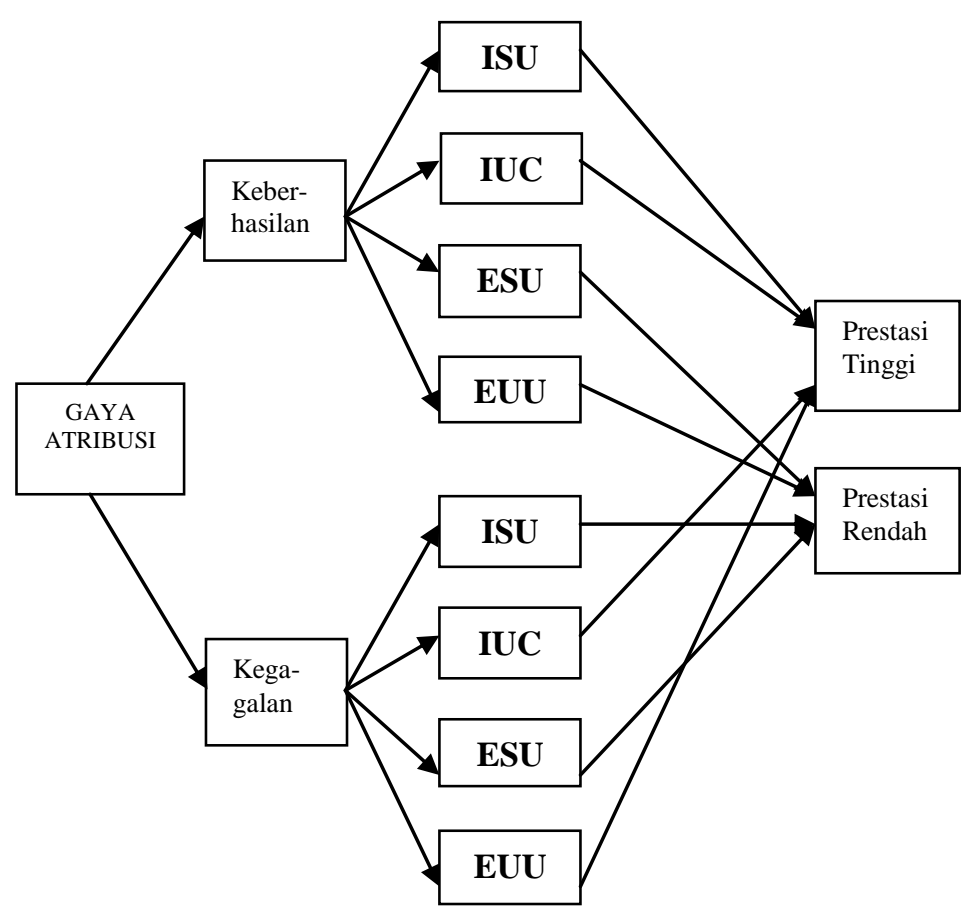

\section{Keterangan:}

ISU: atribusi dengan faktor-faktor dalam dimensi internal-stable-uncontrolable 
IUC: atribusi dengan faktor-faktor dalam dimensi internal-unstable-controllable

ESU: atribusi dengan faktor-faktor dalam dimensi external-stable-uncontrollable

EUU: atribusi dengan faktor-faktor dalam dimensi external-unstable-uncontrollable

Dengan kerangka pemikiran di atas, penulis mengajukan dua hipotesis: "Terdapat hubungan positif antara gaya atribusi siswa dengan tingkat prestasi akademiknya." Hipotesis tersebut dijabarkan ke dalam dua anak hipotesis sebagai berikut:

1) Terdapat hubungan antara gaya atribusi siswa tentang keberhasilan dengan prestasi akademiknya. Hipotesisi ini dijabarkan lagi kedalam empat anak hipotesis sebagai berikut:

(a) Terdapat hubungan antara gaya atribusi keberhasilan pada dimensi internal-stable-uncontrollable (ISU) dengan prestasi akademik.

(b) Terdapat hubungan antara gaya atribusi keberhasilan pada dimensi internal-unstable-controllable (IUC) dengan prestasi akademik.

(c) Terdapat hubungan antara gaya atribusi keberhasilan pada dimensi external-stable-uncontrollable (ESU) dengan prestasi akademik.

(d) Terdapat hubungan antara gaya atribusi keberhasilan pada dimensi external-unstable-uncontrollable

(EUU) dengan prestasi akademik.

2) Terdapat hubungan antara gaya atribusi siswa tentang kegagalan dengan tingkat prestasi akademiknya. Hipotesis ini dijabarkan lagi menjadi empat anak hipotesis sebagai berikut:

(a) Terdapat hubungan antara gaya atribusi kegagalan pada dimensi internal-stable-uncontrollable (ISU) dengan prestasi akademik.

(b) Terdapat hubungan positif antara gaya atribusi kegagalan pada dimensi external-stable-uncontrollable (ESU) dengan prestasi akademik.

(c) Terdapat hubungan positif antara gaya atribusi kegagalan pada dimensi external-stable-uncontrollable (ESU) dengan prestasi akademik.

(d) Terdapat hubungan antara gaya atribusi kegagalan pada dimensi external-unstable-uncontrollable (ISU) dengan prestasi akademik.

\section{Pembahasan Hasil Penelitian}

Dari hasil pengujian hipotesis pertama diperoleh kesimpulan bahwa: (1) terdapat hubungan positif yang signifikan antara gaya atribusi keberhasilan pada dimensi ISU dengan prestasi akademik; (2) terdapat hubungan positif yang signifikan antara gaya atribusi keberhasilan pada dimensi IUC dengan prestasi akademik; (3) terdapat hubungan negatif yang signifikan antara gaya atribusi keberhasilan pada dimensi ESU dengan prestasi akademik; dan (4) terdapat hubungan negatif yang signifikan antara gaya atribusi keberhasilan pada dimensi EUU dengan prestasi akademik. Terhadap hasil-hasil 
tersebut dapat diberikan pembahasan sebagai berikut:

1) Adanya hubungan positif antara gaya atribusi keberhasilan pada dimensi ISU dengan prestasi akademik mengindikasikan bahwa siswa yang mengatribusikan keberhasilan akademiknya dengan faktor-faktor dalam dimensi internal - stable - uncontrolable (ISU) cenderung mencapai prestasi akademik tinggi, sedangkan siswa yang kurang atau tidak mengatribusikan keberhasilan akademiknya dengan faktor-faktor dalam dimensi ISU cenderung mencapai prestasi akademik rendah. Dengan kata lain, siswa yang memiliki keyakinan bahwa keberhasilan akademiknya ditentukan oleh adanya faktor-faktor ISU seperti adanya kemampuan yang tinggi, memiliki sifat rajin, dan menghargai keberhasilan cenderung memiliki (mencapai) prestasi akademik tinggi. Sebaliknya, siswa yang kurang atau tidak memiliki keyakinan akan adanya hubungan kausal antara keberhasilan akademiknya dengan dengan faktor-faktor dalam dimensi ISU cenderung memiliki prestasi akademik rendah. Jika dilihat dari besaran koefisien korelasinya berdasarkan kriteria dari Guilford, hubungan antara kedua variabel tersebut termasuk kurang erat.

2) Adanya hubungan positif antara gaya atribusi keberhasilan pada dimensi IUC dengan prestasi akademik mengindikasikan bahwa siswa yang mengatribusikan keberhasilan akademiknya dengan faktor-faktor dalam dimensi internal - unstable - controllabe (IUC) seperti ketekunan atau kerja keras dalam belajar, minat yang tinggi terhadap pelajaran, sikap positif terhadap belajar dan mata pelajaran, luasnya pengetahuan yang dimiliki, motivasi berprestasi yang tinggi, dan mood untuk belajar cenderung mencapai keberhasilan akademik. Dengan kata lain, siswa yang memiliki keyakinan bahwa prestasi akademiknya tinggi berhubungan dengan faktor-faktor dalam dimensi IUC tersebut cenderung mencapai prestasi akademik yang tinggi. Sedangkan siswa yang kurang mengatribusikan keberhasilan akademiknya dengan faktorfaktor dalam dimensi IUC, atau siswa yang kurang memiliki kayakinan akan adanya hubungan kausal antara keberhasilan akademiknya dengan faktor-faktor dalam dimensi IUC, cenderung kurang berhasil secara akademik atau cenderung mencapai prestasi akademik yang rendah. Jika dilihat dari besaran koefisien korelasinya, hubungan antara kedua variabel termasuk kurang erat.

3) Adanya hubungan negatif antara gaya atribusi keberhasilan pada dimensi ESU dengan prestasi akademik mengindikasikan bahwa siswa yang mengatribusikan keberhasilan akademik dengan faktor-faktor dalam dimensi ESU cenderung memiliki prestasi akademik rendah, sedangkan siswa lain yang kurang atau tidak mengatribusikan keberhasilan akademiknya dengan faktor-faktor dalam 
dimensi ESU cenderung memiliki prestasi akademik tinggi. Dengan kata lain, siswasiswa yang memiliki keyakinan bahwa keberhasilan akademiknya lebih banyak ditentukan oleh adanya karakteristik mata pelajaran yang mudah, karakteristik guru yang baik hati, atau karakteristik guru yang pandai dalam mengajar cenderung mencapai prestasi akademik rendah. Sedangkan siswa yang kurang atau tidak memiliki keyakinan bahwa keberhasilan akademiknya dipengaruhi oleh faktorfaktor dalam dimensi ESU tersebut cenderung mencapai prestasi akademik yang tinggi. Jika dilihat dari besaran koefisien korelasinya, hubungan antara kedua variabel termasuk kurang erat.

4) Adanya hubungan negatif antara gaya atribusi keberhasilan pada dimensi EUU dengan prestasi akademik mengindikasikan bahwa siswa yang mengatribusikan keberhasilan akademiknya dengan faktor-faktor dalam dimensi EUU cenderung memiliki prestasi akademik rendah, sedangkan siswa yang kurang atau tidak mengatribusikan keberhasilan akademiknya dengan faktor-faktor dalam dimensi EUU cenderung mencapai prestasi akademik tinggi. Dengan kata lain, siswa yang memiliki keyakinan bahwa keberhasilan akademiknya dipengaruhi oleh faktor-faktor seperti adanya campur tangan atau bantuan dari orang lain, adanya keberuntungan, adanya kesempatan untuk mencontoh atau menyontek cenderung memiliki prestasi akademik rendah. Sedangkan siswa yang kurang atau tidak memiliki keyakinan bahwa keberhasilan akademiknya berhubungan dengan faktor-faktor dalam dimensi EUU tersebut cenderung mencapai prestasi akademik tinggi. Jika dilihat dari besaran koefisien korelasinya, hubungan antara kedua variabel termasuk cukup erat.

Dari hasil pengujian hipotesis kedua diperoleh kesimpulan bahwa: (1) terdapat hubungan negatif yang signifikan antara gaya atribusi kegagalan pada dimensi ISU dengan prestasi akademik; (2) terdapat hubungan positif yang signifikan antara gaya atribusi kegagalan pada dimensi IUC dengan prestasi akademik; (3) terdapat hubungan negatif yang signifikan antara gaya atribusi kegagalan pada dimensi ESU dengan prestasi akademik; dan (4) terdapat hubungan positif yang signifikan antara gaya atribusi kegagalan pada dimensi EUU dengan prestasi akademik. Terhadap hasil-hasil tersebut dapat diberikan pembahasan sebagai berikut:

1) Adanya hubungan negatif yang signifikan antara gaya atribusi kegagalan pada dimensi ISU dengan prestasi akademik mengindikasikan bahwa siswa yang mengatribusikan kegagalan akademiknya dengan faktor-faktor dalam dimensi ISU cenderung mencapai prestasi akademik rendah, sedangkan siswa yang kurang atau tidak mengatribusikan kegagalan akademiknya dengan faktor-faktor dalam dimensi ISU cenderung mencapai prestasi akademik tinggi. Dengan kata lain, siswa yang memiliki keyakinan bahwa terdapat 
hubungan kausal antara kegagalan akademiknya dengan faktor-faktor dalam dimensi seperti kurangnya kemampuan, sifat malas belajar dan tak menghargai keberhasilan cenderung mencapai prestasi akademik rendah, sedangkan siswa yang kurang atau tidak memiliki keyakinan bahwa kegagalan akademiknya berhubungan dengan faktor-faktor dalam dimensi ISU cenderung memiliki prestasi akademik tinggi. Jika dilihat dari besaran koefisien korelasinya, hubungan antara kedua variabel termasuk erat.

2) Adanya hubungan positif yang signifikan antara gaya atribusi kegagalan pada dimensi IUC dengan prestasi akademik mengindikasikan bahwa siswa yang mengatribusikan kegagalan akademiknya dengan faktor-faktor dalam dimensi IUC cenderung memiliki prestasi akademik tinggi, sedangkan siwa yang kurang atau tidak mengatribusikan kegagalan akademikinya dengan faktor-faktor dalam dimensi IUC cenderung memiliki prestasi akademik rendah. Dengan kata lain, siswa yang memiliki keyakinan akan adanya hubungan kausal antara kegagalan akademiknya dengan faktor-faktor seperti kurangnya upaya atau kerja keras, kurangnya minat terhadap pelajaran, kurangnya sikap positif terhadap belajar, dan badan yang kurang sehat cenderung memiliki prestasi akademik tinggi. Sedangkan siswa yang kurang ataun tidak memiliki keyakinan akan adanya hubungan kausal antara kegagalan akademiknya dengan faktor-faktor dalam dimensi IUC tersebut cenderung memiliki prestasi akademik rendah. Jika dilihat dari besaran koefisien korelasinya, hubungan antara kedua varaibel termasuk cukup erat.

3) Adanya hubungan negatif yang signifikan antara gaya atribusi kegagalan pada dimensi ESU dengan prestasi akademik mengindikasikan bahwa siswa yang mengatribusikan kegagalan akademiknya dengan faktor-faktor dalam dimensi ESU cenderung mencapai prestasi akademik rendah, sedangkan siswa yang kurang atau tidak mengatribusikan kegagalan akademiknya dengan faktor-faktor dalam dimensi ESU cenderung mencapai prestasi akademik tinggi. Dengan kata lain, siswa yang memiliki keyakinan bahwa kegagalan akademiknya dengan faktor-faktor dalam dimensi seperti Tugas atau mata pelajaran yang sulit, guru yang tidak baik, guru yang tidak cakap dalam mengajar cenderung mencapai prestasi akademik rendah, sedangkan siswa yang kurang atau tidak memiliki keyakinan bahwa kegagalan akademiknya berhubungan dengan faktorfaktor dalam dimensi ISU tersebut cenderung memiliki prestasi akademik tinggi. Jika dilihat dari besaran koefisien korelasinya, hubungan antara kedua variabel termasuk erat.

4) Adanya hubungan positif yang signifikan antara gaya atribusi kegagalan pada dimensi EUU dengan prestasi akademik mengindikasikan bahwa siswa yang mengatribusikan kegagalan akademiknya 
dengan faktor-faktor dalam dimensi EUU cenderung memiliki prestasi akademik tinggi, sedangkan siswa yang kurang atau tidak mengatribusikan kegagalan akademikinya dengan faktor-faktor dalam dimensi EUU cenderung memiliki prestasi akademik rendah. Dengan kata lain, siswa yang memiliki keyakinan akan adanya hubungan kausal antara kegagalan akademiknya dengan faktor-faktor seperti kurangnya keberuntungan, penilaian yang tidak obyektif, materi tes yang meyimpang, dan salah dalam memahami petunjuk cenderung memiliki prestasi akademik tinggi. Sedangkan siswa yang kurang atau tidak memiliki keyakinan akan adanya hubungan kausal antara kegagalan akademiknya dengan faktor-faktor dalam dimensi EUU tersebut cenderung memiliki prestasi akademik rendah. Jika dilihat dari besaran koefisien korelasinya, hubungan antara kedua variabel termasuk tidak erat.

Secara keseluruhan, dalam hubungannya dengan keberhasilan akademik, hasil-hasil tersebut di atas menyatakan bahwa para siswa yang mengatribusikan keberhasilan akademiknya dengan kemampuan yang tinggi, karakteristik kepribadian yang positif, kerja keras, luasnya pengetahuan yang dimiliki, kuatnya minat terhadap belajar dan mata pelajaran, kuatnya dorongan untuk berprestasi, dan kondisi fisik yang mendukung cenderung mencapai prestasi akademik yang tinggi. Sedangkan siswa yang mengatribusikan keberhasilan akademiknya dengan karakteristik tugas atau mata pelajaran yang mudah, guru yang baik, guru yang cakap dalam mengajar, keberuntungan, dan adanya campur tangan atau bantuan orang lain baik dalam menyelesaikan tugas maupun soal-soal ujian cenderung memiliki prestasi akademik yang rendah.

Dalam hubungannya dengan kegagalan akademik, siswa yang mengatribusikan kegagalan akademiknya dengan beberapa faktor kurangnya kerja keras atau ketekunan dalam belajar, kurangnya minat terhadap belajar dan mata pelajaran, kurangnya pengetahuan, kurangnya dorongan berprestasi, kurangnya kegairahan belajar, kurangnya keberuntungan, dan pemberian nilai yang kurang obyektif cenderung mencapai prestasi akademik yang tinggi. Sebaliknya, siswa yang mengatribusikan kegagalan akademiknya dengan faktor kurangnya kemampuan, karakteristik tugas atau mata pelajaran yang sulit, guru yang tidak baik, guru yang tidak bisa mengajar, dan tidak adanya bantuan cenderung mencapai prestasi akademik rendah.

Hasil-hasil tersebut di atas memberikan konfirmasi lebih lanjut yang mendukung hasilhasil penelitian terdahulu dan teori-teori atribusi pada umumnya dan teori atribusi Weiner pada khususnya seperti telah diuraikan pada Bab II. Meskipun peran motivasi berprestasi tidak diteliti dalam penelitian ini, terjadinya perbedaan dalam prestasi akademik antara siswa yang memiliki gaya atribusi keberhasilan dan atribusi kegagalan akademik yang berbeda diduga disebabkan oleh karena setiap bentuk gaya atribusi memiliki pengaruh langsung pada harapan dan motivasi 
berprestasi. Siswa yang mengatribusikan keberhasilan akademiknya dengan faktorfaktor dalam dimensi ISU dan dengan faktorfaktor dalam dimensi IUC, serta mengatribusikan kegagalan akademiknya dengan faktor-faktor dalam dimensi IUC dan EUU diduga lebih memiliki harapan dan motivasi untuk berhasil pada kinerja akademik selanjutnya. Sebab, jika mereka percaya bahwa dirinya memiliki kemampuan yang tinggi dalam bidang yang ditekuni, dan percaya bahwa keberhasilan dipengaruhi oleh jumlah usaha yang dikeluarkan, dan kegagalan yang dialaminya berhubungan dengan kurangnya upaya, karena sedang kurang beruntung, atau disebabkan oleh faktor-faktor eksternal tidak stabil/dapat berubah, mereka lebih mungkin untuk dapat mencapai hasil yang berbeda pada kinerja akdemik selanjutnya. Sebaliknya, jika siswa memiliki keyakinan bahwa keberhasilannya dalam memperoleh nilai tinggi lebih disebabkan adanya dukungan faktor-faktor eksternal yang tak dapat dikendalikan, baik yang bersifat stabil maupun tidak stabil, seperti tugas atau mata pelajaran yang mudah, guru yang baik hati, guru yang pandai mengajar, keberuntungan, dan adanya bantuan, serta memiliki keyakinan bahwa prestasi akademiknya yang rendah disebabkan oleh karena ia kurang memiliki kemampuan atau karena sifat mata pelajaran yang sulit, maka siswa tersebut cenderung untuk kurang memiliki harapan dan motivasi untuk berhasil pada kinerja akademik selanjutnya. Pada gilirannya prestasi akademik siswa tersebut cenderung rendah.

\section{Simpulan}

Berdasarkan pada hasil analisis yang telah dilakukan diperoleh kesimpulan umum bahwa gaya atribusi siswa tentang keberhasilan dan kegagalan akademik berkorelasi dengan prestasi akademiknya. Gaya atribusi keberhasilan akademik dengan faktor-faktor internal yang bersifat stabil dan tak dapat dikendalikan (ISU) dan dengan faktor internal tak stabil yang dapat dikendalikan (IUC) berkorelasi positif dengan prestasi akademik siswa. Gaya atribusi keberhasilan dengan faktor-faktor dalam dimensi eksternal yang tak dapat dikendalikan, baik yang bersifat stabil (ESU) maupun tak stabil (EUU) berkorelasi negatif dengan tingkat prestasi akademik siswa. Gaya atribusi kegagalan akademik dengan faktor-faktor dalam dimensi IUC dan EUU berkorelasi positif dengan tingkat prestasi akademik, dan gaya atribusi kegagalan akademik dengan faktor-faktor dalam dimensi ISU dan ESU berkorelasi negatif tingkat prestasi akademik.

Secara khusus dapat dibuat dua kesimpulan. Dalam hubungannya dengan keberhasilan akademik, siswa yang mengatribusi keberhasilan akademiknya dengan faktor-faktor internal yang tidak stabil dan yang dapat dikendalikannya seperti ketekunan atau kerja keras dalam belajar, minat yang tinggi dan sikap positif terhadap belajar dan mata pelajaran, luasnya pengetahuan, serta kondisi fisik dan suasanan hati yang mendukung cenderung mencapai prestasi akademik tinggi. Sedangkan siswa mengatribusikan keberhasilan akademiknya 
dengan faktor-faktor eksternal yang tak dapat mereka kendalikan seperti karakteristik tugas atau mata pelajaran yang mudah, guru yang baik, dan guru yang cakap dalam mengajar, serta faktor-faktor eksternal yang bersifat tak stabil dan tak dapat dikendalikan seperti keberuntungan, kesempatan menyontek, dan adanya bantuan cenderung memiliki prestasi akademik rendah.

Dalam hubungannya dengan kegagalan akademik, siswa yang mengatribusikan kegagalan akademiknya dengan faktor-faktor internal yang tidak stabil dan yang dapat mereka kendalikan seperti kurangnya ketekunan dalam belajar, kurangnya pengetahuan, kurangnya minat, kurangnya kesiapan, dan kurangnya dorongan untuk berprestasi, kondisi badan yang kurang sehat, serta dengan faktor-faktor eksternal yang dapat berubah dan tak dapat dikendalikan seperti sedang tidak beruntung, materi tes yang tidak sesuai atau tidak jelas, guru yang tidak obyektif, dan adanya kesalahan dalam memahami petunjuk cenderung memiliki prestasi akademik tinggi. Sebaliknya, para siswa berprestasi rendah cenderung mengatribusikan prestasi akademik mereka yang rendah dengan faktor-faktor internal yang relatif permanen dan tak dapat dikendalikan seperti kurangnya kemampuan dan adanya karakteristik kepribadian yang negatif, di samping dengan faktor-faktor eksternal yang relatif permanen dan tak dapat dikendalikan seperti karateristik mata pelajaran yang sulit, mata pelajaran yang tak menarik, dan guru yang tidak baik atau tidak cakap dalam mengajar.

Gaya atribusi keberhasilan dan kegagalan akademik yang dipegang oleh para siswa di SMAN 4, SMAN 8, dan SMAN 11 berhubungan dengan prestasi akademiknya. Meskipun demikian perlu diingat bahwa prestasi akademik merupakan suatu bentuk ekspresi perilaku yang dipengaruhi oleh banyak faktor, atau merupakan fungsi dari berbagai faktor pengaruh. Dengan kata lain, gaya atribusi hendaknya dipahami hanya sebagai salah satu faktor dari sejumlah faktor yang diduga ikut memainkan peran penting dalam mempengaruhi kinerja akademik dan tingkat prestasi akademik para siswa di empat SMA Negeri yang dijadikan lokasi dalam penelitian ini.

Berdasarkan hasil-hasil penelitian ini, gaya atribusi keberhasilan dan kegagalan yang dibuat oleh siswa dalam hubungannya dengan kegiatan akademiknya di sekolah dapat dijadikan sebagai salah satu faktor yang perlu diperhatikan dalam merancang dan/atau mengembangkan suatu program bantuan atau intervensi. Dengan kata lain, berbagai program bantuan atau intervensi psikologis untuk maksud menangani prestasi akademik rendah atau untuk meningkatkan prestasi akademik dapat dilakukan antara lain dengan cara mendorong siswa untuk membuat atribusi akademik yang adaptif, yakni mengatribusikan keberhasilan akademiknya dengan faktorfaktor internal yang bersifat stabil dan tak dapat dikendalikan (ISU), dan dengan faktorfaktor internal tak stabil yang dapat 
dikendalikan (IUC), serta mengatribusikan kegagalan akademiknya dengan faktor-faktor internal tak stabil yang dapat dikendalikan (IUC) dan dengan faktor eksternal tak stabil yang tak dapat dikendalikan (EUU).

\section{Daftar Pustaka}

A.E. Woolfolk, (1995). Educational Psychology. $6^{\text {th }}$. Ed. Boston: Allyn and Bacon

B. Weiner, (1986). An Atribution Theory of Motivation and Emotion. New York: Springer-Verlag.

-------, (1979). A theory of motivation for some classroom experience. Journal of Education Psychology,.

D. Perlman \& P.C. Cosby, (1983). Social Psychology. New York: Holt, Rinehart and Winston.

D.R. Shaffer (1994). Social \& Personality Development. $\quad 3^{\text {rd. }}$ ed. California: Brooks/Cole Publishing Company.

H.C. Lindgren, H.C. (1981). Educational Psychology in the Classroom. New York: Oxford University Press.

J.T. O'Sullivan \& M.L. Howe, (1996). "Causal Attribution and reading Achievement: Individual Differences in Low-Income Families." Contemporary Educational Psychology. Article No. 0027.

Laurence Steinberg, (1993). Adolescence. International edition. $3^{\text {rd }}$. ed. New York: McGraw-Hill, Inc.

Luzzo, D.A., James, T.J., \& Luna, M. (1996). Effects of Attributional Retraining on the Career beliefs and Career Exploration Behavior 
Psympathic, Vol. I, No.1, 2008: 33 - 46 